bonate to make good the protein deficiency in cereal and other starchy foods, nor the doubling of the existing acreage under beans, would appreciably add to our resources in protein materials. More hopeful would be the economizing of imported feeding-stuffs by adopting the Lehmann system of pig-feeding (restricting the cereal meals and using more boiled roots, potatoes, etc.); the reduction in the protein ration of dairy cows from $0.6 \mathrm{lb}$. to $0.5 \mathrm{lb}$. protein equivalent per gallon of milk; and by putting all poultry on minimum feeding allowances. These savings would represent about three times those to be secured from possible new sources of supply. The total savings from all sources would represent $11 \cdot 7$ per cent protein equivalent and 8.9 per cent starch equivalent of our pre-War home production, but only 8.5 and 6.9 per cent, respectively, of our total preWar supplies.

\section{The Pharmaceutical Society's New House}

The Pharmaceutical Society's building in London was nearing completion when the exigencies of the War brought about a suspension of the final stage of the building operations, and so prejudiced the intention of celebrating the centenary in a new home. The council of the Society, having in mind the fact that the lease of the old building in Bloomsbury Square will expire in due course, is approaching the Ministry of Works with the proposal that, in return for facilities being granted to finish the building, the Government should have the option of the use of it during the present emergency. This offer may raise the general question of the attitude of the Government regarding large modern buildings in London which are nearing completion.

The Society's new building has a frontage of $235 \mathrm{ft}$. and a site depth of $120 \mathrm{ft}$. ; it is designed to provide a basement, ground floor and five upper stories, and the total available floor area which could be provided would be more than 141,000 square feet. The main front block and the west and centre wings have been erected up to the fourth floor level. The east block remains to be built from above basement level. The building is of steel frame construction with panel walls finished on the outside in brickwork with stone and slate dressings ; the floors are of reinforced concrete. Since the accommodation contemplated covered the provision of laboratories, two lecture theatres, an assembly hall, library, refectory with kitchen and administrative offices, there are available large open and well-lighted floor areas readily adaptable to office or other similar requirements.

\section{Germany's Aluminium Industry}

Tне Engineer is publishing a series of illustrated articles entitled "Air Force Targets in Germany", in which much information is given about the docks, harbours, canals, factories, railways and power stations which are so often in the news. Three of the latest articles to appear, published respectively on October 18 and 25 and November 1, deal generally with Germany's aluminium industry and especially with the large works at Lauta, to the north-west of
Dresden, at Bitterfeld in the Leipzig district and at Rheinfelden in the extreme south-west of Germany. The last is the oldest works, having been started in 1898, while the other two were planned in 1915-17 to meet the needs of the time. Each of the works consist of three main sections; an electric generating and transforming station, factories housing the groups of electrolytic baths or furnaces and foundries in which the metal is cast into ingots and bars and rolled into sections and sheets. The raw materials needed for the production of one ton of aluminium are 4 tons of bauxite, 80 kilos of artificial cryolite, about 600 kilos of carbon electrodes, and some $23,000 \mathrm{kw}$. of electric energy. The process time varies from 100 to 130 hours. In 1929 Germany's output of aluminium was 33,000 metric tons out of a world total of 282,000 tons and by 1938 it had risen to 163,600 tons out of a world output of 579,900 . More than 70 per cent of Germany's light alloy manufacturing capacity is Government owned, and every effort has been made to extend the use of these light alloys and to manufacture them from homeproduced raw materials.

\section{Telegraphic Typesetting}

A PAPER on telegraphic typesetting by $\mathrm{H}$. $\mathrm{H}$. Harrison read and discussed before the Institution of Electrical Engineers appears in the Journal of the Institution of October. In the discussion, Mr. D. Murray pointed out that the paper is valuable because it reminds us that, in addition to strong stream and weak stream technique, there are controlling electro-mechanisms of the most remarkable character, correctly described as electrical typewriterkeyboard machines, of great complexity and beauty. The teletype, one of these keyboard machines, of which the fundamental characteristic is the transmission of intelligence by semi-mechanical machines (telegraph class of mechanisms), is in wide use in the form of a telegraph exchange, analogous to a telephone exchange, covering the whole of the territory of the United States, with about 15,000 subscribers. Considerable progress was being made in this direction in Great Britain also, and plans were being considered for spreading the exchange all over Europe. Unfortunately, this development has been interrupted by the War.

Mr. Harrison's paper deals with an astonishing extension of the telegraph-keyboard mechanism that combines the typewriter-keyboard mechanism with typesetting at a distance. Mr. Murray saw it in operation at the Western Electric Teletype factory in Chicago about three years ago. It was shown to him as an example of successful prophecy, because about forty years previously he had exhibited a typewriter telegraph of this class at the old Astor House in lower Broadway with the slogan "This tape sets type". He had brought the model from Australia and it attracted much attention. In his reply, Mr. Harrison said that Mr. Murray's forty-year-old prophecy was an interesting example of the slow growth of ideas. Although the Monotype keyboard producing a perforated tape and provided with an 
integrating counting mechanism was then available and was also as remotely situated from the type producer (the caster) as the present telegraphic typesetter keyboard, yet it is only comparatively recently that telegraphic typesetting has been accomplished.

\section{Reducing Noise in Enclosed Spaces}

Durrng the last two years, progress has been made in the problem of noise reduction, especially in sound-proofing rooms against the transmission of external noise. In Engineering of October 25 the allied problem is described of sound-proofing rooms by using Accousti-Celotex tiles of sugar-cane fibre, manufactured by Messrs. Celotex, Ltd., Stonebridge Park, London, N.W.10. Under present-day conditions, many offices, etc., are more congested, with resultant increased noise. It is of interest, therefore, to cite certain data on sound absorption in offices which have recently become available. They are derived from tests made in the offices of an insurance company in the United States. This company has had about 300,000 square feet of Accousti-Celotex tiling fitted to its offices. Records were kept for a year preceding the fitting of the tiles and for a year after they had been installed. In two selected rooms, the increase of efficiency of the persons working therein was respectively $9 \cdot 2$ per cent and $7 \cdot 7$ per cent. 'Typists' errors were reduced by 29 per cent, and calculating machine operators' by 52 per cent.

It would appear that apparent loudness or annoyance increases much more rapidly at the higher loudness levels (in phons) than it does at the lower sound-levels, with the result that a relatively small reduction in phons at the higher levels decreases the apparent loudness very considerably. Thus it was found that a 7 -phon reduction in a typing room with an average maximum loudness of 70 phons results in a decrease of 43 per cent in the apparent loudness or real annoyance, which condition is equivalent to the effect gained by the removal of about 80 per cent of the noise-making units. It is of interest to note that the tiles, from the material employed, are of light weight and are not affected as regards their soundabsorbing properties by painting. The grade of tile fitted in any particular case varies with the amount of noise normally present and the amount of absorption desired.

\section{Mineral Resources of South Africa}

The Executive Committee of the Third Empire Mining and Metallurgical Congress, which met in South Africa in 1930, prepared for the Congress a review of the mineral resources of the Union of South Africa. The success which attended the issue of this book led to its revision in 1936, and now, in 1940, the Department of Mines has published a third and again thoroughly revised edition. Introductory chapters deal with the geography and geology and with various historical and legal aspects of the mineral industry; but the bulk of the work, which extends to 544 pages, is devoted to individual economic minerals, of which the chief, in order of total output, are gold, diamonds, coal, copper ores, tin ores, asbestos, silver ores and the platinum metals.

Recent expansion of mining activity in the case of gold has led to results which indicate that former estimates of the future life of the goldfields were below the true figure. The opinion now expressed is that unless gold materially decreases in value, the future of gold mining in South Africa is secure for many decades to come. Diamond mining has recently been almost at a standstill, apart from the alluvial fields; existing reserves are sufficient to maintain normal production for nearly a century. Similarly, there are immense reserves of platinum in the Bushveld complex, and when prices become more favourable a great expansion of this branch of the industry is inevitable. Of coal and iron the Union possesses vast resources, coal being sufficient to provide for the needs of the country for many centuries. The book is copiously illustrated and well provided with maps and statistical tables, and will prove to be of great interest to a wide variety of readers.

\section{Indian Association for the Cultivation of Science}

THE annual report for the year 1939 of the Indian Association for the Cultivation of Science includes as an appendix a report by Prof. K. S. Krishnan on the scientific work of the Association. This has included investigations on the magnetic properties of a free-electron gas with the view of determining the energy distribution, and Pauli's observation of a feeble paramagnetism independent of temperature in the electron gas has been verified for several metals. Landau's discovery of the appreciable diamagnetism of an electron gas has been experimentally verified, and recent measurements by Prof. Krishnan and Mr. N. Ganguli have shown that the conductivity of graphite in the basal plane is at least 10,000 times that along the normal to the plane. Other investigations have related to the mobile electrons in aromatic molecules, the diamagnetism of aromatic molecules, optical studies on aromatic molecules, magnetic studies on bismuth in the neighbourhood of its melting point, and paramagnetic studies on single crystals of the salts of the rare earth and the iron groups of metals, as well as structural studies on organic crystals, including the halogen derivatives of benzoquinone and related compounds. Notes on some spectroscopic work on the sulphides of the transitional group of elements and on the discovery of a new ionization layer in the upper atmosphere are also included.

\section{Replenishing the Fauna of the Caspian}

As a first measure to replenish the fauna of the Caspian-a problem on which the Soviet Ichthyological Research Institute has been working for some years-Nereis, the Polychrte worm relished by the sturgeon, bream and other fish, is to be brought to this land-locked sea from the Azov. The worm will be transported from the Azov Sea in isothermal boxes and put into the Caspian. Experiments carried out during the past three years have proved the 